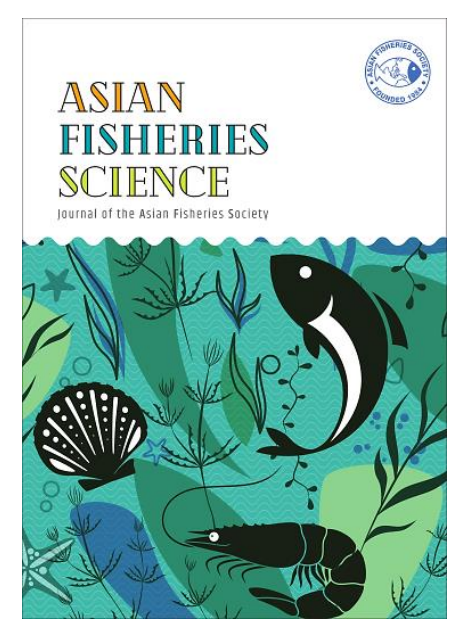

\title{
Value Chain Analysis of the Horse Mussel Modiolus metcalfei (Hanley, 1843) Fishery in lloilo, Philippines
}

\author{
KAENT IMMANUEL UBA ${ }^{1, *}$, HAROLD MONTECLARO², MARY MAR NOBLEZADA-PAYNE ${ }^{2}$, GERALD \\ QUINITIO ${ }^{2}$, JON ALTAMIRANO ${ }^{3}$ \\ 'School of Marine Fisheries and Technology, Mindanao State University at Naawan, Pedro Pagalan St., Poblacion, Misamis Oriental, \\ Naawan 9023, Philippines \\ ${ }^{2}$ College of Fisheries and Ocean Sciences, Institute of Marine Fisheries and Oceanology, University of the Philippines Visayas, Miagao, \\ Iloilo 5023, Philippines \\ ${ }^{3}$ Aquaculture Department, Southeast Asian Fisheries Development Center, lloilo, Philippines \\ *E-mail: kaentimmanuel.uba@msunaawan.edu.ph | Received: 14/09/2019; Accepted: 07/05/2020
}

(ㄷ) Asian Fisheries Society

ISSN: 0116-6514

E-ISSN: $2073-3720$

https://doi.org/10.33997/j.afs.2020.33.2.003

\begin{abstract}
The exploitation of horse mussels Modiolus metcalfei(Hanley, 1843) in Dumangas, lloilo has been going on for decades, yet effective fisheries management remains hindered by the poor understanding of the fishery. A value chain analysis was conducted to provide a better understanding of the horse mussel fishery in the area and identify upgrading strategies. Mapping of the value chain used data gathered through fisherfolk interviews, key informant interviews, and field observations. The collectors, processors, retailers, and ambulant vendors are the key players in the fishery. It is a sphere of both men and women who create value additions along the chain. While both men and women may engage in marketing, the majority of men are involved in the collection while women do the processing. The collectorcum-ambulant vendor benefits the most with a monthly income of PHP10,892.78 (USD217.86) with value addition of PHP8.30 kg-1 (USD0.17), followed by the collector with a monthly income of PHP9,597.46 (USD191.95) with a value addition of PHP4.00 kg-1 (USD0.08) and retailer with a monthly income of PHP5,000.00 (USD100.00) with value addition of PHP4.55 kg-1 (USD0.09). The actor who benefits the least in this value chain is the processor with a monthly income of PHP4,185.10 (USD83.70) with value addition of PHP2.30 kg-1 (USD0.05). Upgrading strategies at every node of the value chain along with its enabling strategies were proposed to improve the income of key actors and maximise the economic benefits from the horse mussel fishery.
\end{abstract}

Keywords: Modiolus metcalfei, food security, resource exploitation, fisheries management

\section{Introduction}

In the Philippines, mussels are an important fishery resource with only three species exploited commercially, namely, Perna viridis (Linneaus, 1758), Modiolus metcalfei (Hanley, 1843), and Modiolus philippinarum (Hanley, 1843). The green mussel, P. viridis, is commercially farmed with its production entirely sustained by the abundance of wild seeds while the horse mussels, $M$. metcalfei and $M$. philippinarum, are gathered from the wild, as they are not known to attach on substrates other than living adults growing in dense mats on muddy bottoms (Yap, 1978).

Mussel production in the country averaged about 53,932 MT from 2015 to 2017 with Western Visayas as the highest producing region. Production was valued at PHP835,469.25 (USD16,709.39) per year (PSA, 2018). However, these data lumped the production of all commercially exploited mussels in the country (Philippine Statistics Authority, personal communication).

Historical accounts suggest that the harvesting of horse mussels M. metcalfei, locally known as "tahong" or "amahong" in Dumangas, lloilo began in the 1970s, providing food and livelihood to coastal-dwelling families. Today, the horse mussel fishery has expanded and has significant contributions to livelihoods and income of fishers and their families (Napata and Andalecio, 2011).

Dumangas is a coastal municipality in the province of Iloilo, central Philippines with a $21.6 \mathrm{~km}$ coastline stretching along seven coastal communities. It has a 
total population of 66,108 , of which, 12,803 are living in the coastal barangays (National Statistics Office, 2010). The majority of the coastal area of Dumangas is devoted to aquaculture of milkfish and prawns $(4,535$ ha of marine and brackish water fishponds), transportation (it hosts one of the major seaports of the province), and to a lesser extent as settlement of coastal communities. Fishing gears used in the area include lift nets, fish corral, gill nets, pots, hook and line, push nets, and barrier nets (Monteclaro et al., 2010).

Natural beds of the horse mussel can be found in the 21.6-km stretch of coastline covering an estimated area of $26.4 \mathrm{ha}$. These resources support the livelihood of locals and provide a cheap source of protein (Napata and Andalecio, 2011). Although used primarily as food, horse mussels are also fed to high-value cultured species like mangrove crabs (Scylla spp.) and prawns (Penaeus spp.) (Rochanaburanon, 1980), hence this species has been harvested year-round since the 1970s (Napata and Andalecio, 2011).

Due to its importance in the livelihood and income of fishers in the coastal areas in the Philippines, examining the value chain of horse mussel fishery can provide an understanding of the fishery which is vital for upgrading and resource management. A value chain analysis describes the full range of activities required to bring a product or service from conception to the final consumer, including designing, production, marketing, distribution, and after-sales services. Since its introduction in 1985, value chain analysis is used as a tool to understand income distribution among players (Porter, 1985; Kaplinsky and Morris, 2001). Also, it is useful in identifying upgrading in a product or service to gain enhanced value. Recently, value chain analysis has been used to provide insights that are useful for small-scale fisheries management (Rosales et al., 2017).

The present study was done in an attempt to: a) describe the horse mussel value chain in lloilo, Philippines including the examination of its governance and analysis of industry strengths, weaknesses, opportunities, and threats; b) estimate the value addition done by the key players; and c) identify upgrading strategies to maximise the economic benefits from the fishery.

\section{Materials and Methods}

The study was carried out from January to March 2019 in two barangays in Dumangas, Iloilo, where the highest number of horse mussel collectors resided: Barangays Bacay and Lacturan (Fig. 1). Although landlocked, residents of Barangay Lacturan collected horse mussels in the coastal waters of Barangay Bacay. A sex-aggregated survey of actors along the value chain was undertaken. The respondents included 38 gatherers, eight processors, three retailers, 14 ambulant vendors, and three local government officials (key informants). The interviews were conducted using a survey questionnaire which included the following parts: a) demographic characteristic of actors and methods of collection, processing, and trading (retailing and ambulant vending); b) estimation of activities, cost, and schedules; c) governance; and d) industry strengths, weaknesses, opportunities, and threats.

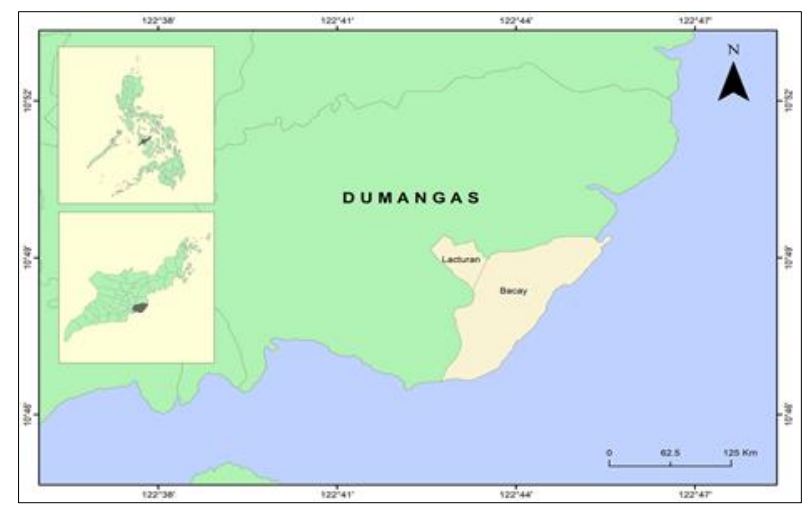

Fig. 1. Location where the value chain analysis on the horse mussel Modiolus metcalfei was conducted.

This value chain analysis used the framework developed by Porter (1985) and expanded in making value chains work better for the poor (M4P, 2008). The point of entry for undertaking this value chain study was to identify specific income increasing strategies for horse mussel fisherfolk. Following that framework, the value chain diagram of horse mussels in Dumangas, lloilo is shown in Figure 2. The distribution of products among actors in the value chain diagrams followed that of Sinh et al. (2014).

Value added was calculated using the formula by Sinh et al. (2014):

Value added $=$ Selling price - Purchase price including the added cost

\section{Results}

\section{The product and the market}

The harvested horse mussels from the coastal waters in Dumangas, lloilo were either sold fresh or processed. Fresh mussels were sold shucked "tinala" and shell-on while processed mussels were salted, added with coconut vinegar, and bottled. Majority of horse mussels were sold in processed form (about $80.0 \%$ ) while the rest was sold as fresh, either shucked or shell-on. These product forms were sold within the municipality of Dumangas and in nearby municipalities (Fig. 3). In the south, it reached as far as Oton, lloilo while in the north it reached as far as Banate, lloilo. 


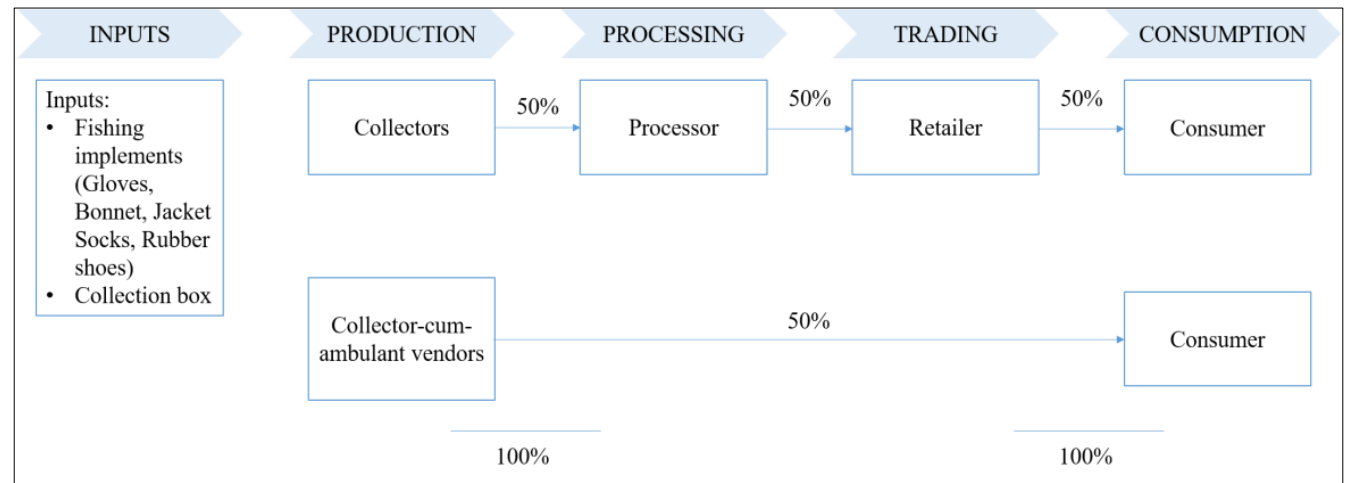

Fig. 2. Mapping of the value chain of the horse mussel Modiolus metcalfei in Dumangas, Iloilo.

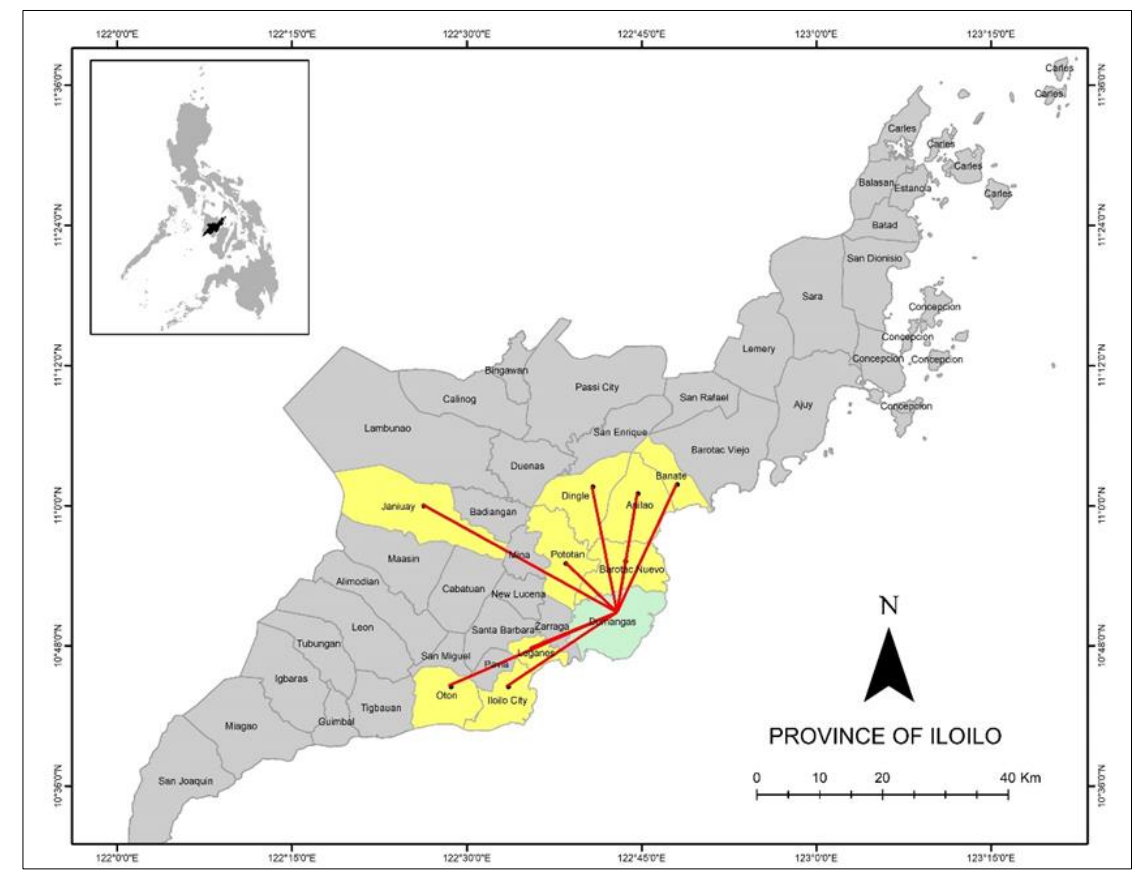

Fig. 3. Map showing the distribution of horse mussel Modiolus metcalfei products from Dumangas, lloilo.

\section{The horse mussel value chain}

The horse mussel value chain consisted of a sequence of productive processes beginning with the provision of specific inputs for horse mussel collection to processing, trading, and finally, consumption (Fig. 4). The horse mussel value chain can be viewed as a series of institutional arrangements linking collectors, processors, traders, and consumers. Every actor in the value chain had specific activities supported by the enablers. At every node, value was added, thereby generating more incomes, investments, and employment.

\section{The key actors, activities, and linkages}

The collectors, processors, retailers, and collectorcum-ambulant vendors were the key actors in the horse mussel value chain.

\section{Collectors}

A collector was male $(90.0 \%)$ who was less than 40 years old $(53.3 \%)$, had finished secondary education $(60.0 \%)$, married $(76.7 \%)$ with a household size of fewer than five individuals $(60.0 \%)$, a full-time gatherer with less than 10 years of experience in collecting horse mussel $(60.0 \%)$, and member of a fisherfolk organisation (56.7 \%) (Table 1). The harvesting of horse mussel was the major source of income of collectors $(90.0 \%)$ while others relied primarily on fishing $(10.0 \%)$. Additional income of collectors came from fishing (16.7\%) and farming (6.7 $\%)$. The collection of horse mussel was done all year round. Majority of the collectors $(51.4 \%$ ) harvested daily while others harvested at a minimum of three to six days in a week. The harvesting of horse mussel was tide-dependent with harvesting done mostly during low tide. However, harvest may be performed even during high tide or slack tide if there was a demand from traders. Most harvests $(60.0 \%)$ were performed either at day, night or dawn, while others $(40.0 \%)$ preferred to harvest only during the day. 


\begin{tabular}{|c|c|c|c|c|c|}
\hline & INPUTS & PRODUCTION & PROCESSING & TRADING & CONSUMPTION \\
\hline 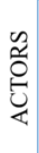 & $\begin{array}{l}\text { Suppliers of } \\
\text { fishing } \\
\text { implements; } \\
\text { fabricator of the } \\
\text { collection box }\end{array}$ & $\begin{array}{l}\text { Horse mussel } \\
\text { collectors }\end{array}$ & $\begin{array}{l}\text { Processors of } \\
\text { fresh and bottled } \\
\text { horse mussels }\end{array}$ & $\begin{array}{l}\text { Horse mussel } \\
\text { collector-cum- } \\
\text { ambulant vendor; } \\
\text { retailer }\end{array}$ & Consumers \\
\hline 覧 & $\begin{array}{l}\text { Buy fishing } \\
\text { implements } \\
\text { (gloves, rubber } \\
\text { shoes, socks, } \\
\text { jacket, bonnet); } \\
\text { prepare the } \\
\text { collection box }\end{array}$ & $\begin{array}{l}\text { Collection of } \\
\text { horse mussels; } \\
\text { cleaning; and } \\
\text { sacking }\end{array}$ & $\begin{array}{l}\text { Shucking; } \\
\text { washing; } \\
\text { draining; addition } \\
\text { of vinegar; and } \\
\text { bottling }\end{array}$ & $\begin{array}{l}\text { Ambulant } \\
\text { vending of fresh } \\
\text { produce; bulk } \\
\text { buying and } \\
\text { retailing of } \\
\text { bottled horse } \\
\text { mussels }\end{array}$ & Prepare; consume \\
\hline 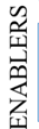 & \multicolumn{5}{|c|}{ Local Government of Dumangas; Academe } \\
\hline
\end{tabular}

Fig. 4. Processes, activities, and key actors in the horse mussel Modiolus metcalfei value chain in Dumangas, lloilo.

Table 1. Profile of horse mussel Modiolus metcalfei collectors in Dumangas, Iloilo ( $n=30)$.

\begin{tabular}{|c|c|c|}
\hline \multicolumn{2}{|l|}{ Characteristics } & \multirow{2}{*}{$\begin{array}{l}\text { Percent }(\%) \\
90.0\end{array}$} \\
\hline Sex & Male & \\
\hline & Female & 10.0 \\
\hline \multirow{5}{*}{ Age } & $\leq 20$ & 3.3 \\
\hline & $21-30$ & 33.3 \\
\hline & $31-40$ & 16.7 \\
\hline & $41-50$ & 20.0 \\
\hline & $51-60$ & 26.7 \\
\hline \multirow[t]{2}{*}{ Marital status } & Single & 23.3 \\
\hline & Married & 76.7 \\
\hline \multirow[t]{3}{*}{ Educational level } & Primary & 26.7 \\
\hline & Secondary & 60.0 \\
\hline & Tertiary & 13.3 \\
\hline \multirow[t]{3}{*}{ Household size } & $1-5$ & 60.0 \\
\hline & $6-10$ & 33.3 \\
\hline & $>10$ & 6.7 \\
\hline \multirow[t]{2}{*}{ Status } & Full time & 80.0 \\
\hline & Part-time & 20.0 \\
\hline \multirow[t]{2}{*}{ Major source of income } & Horse mussel collecting & 90.0 \\
\hline & Fishing & 10.0 \\
\hline \multirow[t]{3}{*}{ Other sources of income } & Fishing & 16.7 \\
\hline & Farming & 6.7 \\
\hline & None & 76.7 \\
\hline \multirow[t]{2}{*}{ Years of experience } & $1-10$ & 60.0 \\
\hline & $11-20$ & 40.0 \\
\hline \multirow[t]{2}{*}{ Membership in fisherfolk organisation } & Member & 56.7 \\
\hline & Non-member & 43.3 \\
\hline
\end{tabular}

The process involved the removal of lumps of horse mussel from the substrate in depths up to $1.5 \mathrm{~m}$ during low tide. Gloves, rubber shoes, and socks were necessary implements during harvesting to minimise cuts as horse mussels have sharp shell edges. The use of a jacket and bonnet would protect a collector from the heat of the sun.

The collected mussels were placed inside a rectangular collection box, locally called "ayagan". It was made of bamboo measuring $1.2 \mathrm{~m} \times 1.8 \mathrm{~m} \times 0.5 \mathrm{~m}$ made afloat by empty plastic containers. Once filled, the horse mussels were shaken inside the collection box with the aid of the foot and with a kicking motion to dislodge the mud, byssal threads, and other debris, as well as to individually separate the horse mussels. During low tide, horse mussels were handpicked, but at high tide, gatherers had to dive to collect.

The horse mussel fishery in Dumangas, lloilo was small-scale. A collector's daily landings ranged from one to four sacks (about $50 \mathrm{~kg}$ per sack). Despite an ordinance limiting daily harvest per collector at two sacks, $20 \%$ of collectors are harvesting beyond what 
was allowed. According to mussel collectors, the major challenges in the horse mussel fishery included weather disturbances, strong waves and typhoons $(80.0 \%)$, encroachment by other collectors from other barangays (34.3\%), difficulty in harvesting (28.6 $\%)$, and depletion of stocks (5.7\%).

\section{Processors}

The wives of the collectors usually served as processors of the horse mussels. A processor was above 40 years old $(87.5 \%)$, had finished secondary education (50.0\%), belonged to a household of fewer than 10 individuals $(100.0 \%)$, and worked fulltime as processors (87.5\%) (Table 2). About $12.5 \%$ of processors were also engaged in fishing activities and $38.0 \%$ of processors were also collectors of horse mussels.

After receiving horse mussels from their husbands, processors immediately began the post-harvest process of all horse mussels received. Their role was crucial in this value chain as they were responsible for the creation of a new product from the freshly collected horse mussels. Processing involved shucking, washing, salting, draining, and bottling. These activities were tedious and time-consuming with the entire process lasting up to four days.

\section{Retailers}

Retailers were those who sold horse mussels within the locality. Unlike processors who were generally based in coastal villages, retailers were usually located in other towns. Retail procurement was mostly limited to processed products. In contrast, processors were primary buyers of fresh horse mussel. Based on interviews, retailers purchased from processors about 100 bottles ( $375 \mathrm{~mL}$.bottle $\mathrm{e}^{-1}$ ) of processed horse mussel weekly and sold the product directly to consumers in main towns within the province.

\section{Collector-cum-ambulant vendors}

The collector-cum-ambulant vendor collected one sack of horse mussels daily, as this was the maximum capacity that their motorcycles could carry for ambulant vending. They sold the fresh horse mussels and the unsold mussels were processed. They sold their harvest in nearby municipalities using a motorcycle for transport. Most of the ambulant vendors sold their products within Dumangas and neighbouring municipalities such as Barotac Nuevo and Leganes. Others went as far as Anilao, Janiuay, Dingle, Banate and Pototan which are about 20 to 30 $\mathrm{km}$ from the collection site (Fig. 3).

Overall, the collection of horse mussels was a maledominated activity, although a few women engaged in this activity. On the other hand, the processing aspect was female-dominated. These women were usually the wives of the collectors who were assisted by their children. The ambulant vendors were men while most retailers were women. The flow of the product among these actors are shown in Figure 5.

The relationships, called linkages, can be both formal and informal arrangements between two actors in the value chain (M4P, 2008). The relationships of these key actors in the horse mussel value chain are shown in Figure 6.

Table 2. Profile of horse mussel Modiolus metcalfei processors in Dumangas, Iloilo $(n=8)$.

\begin{tabular}{lll}
\hline Characteristics & & Per cent $(\%)$ \\
\hline Sex & Male & 0.0 \\
Age & Female & 100.0 \\
& $31-40$ & 12.5 \\
Marital status & $41-50$ & 37.5 \\
& $51-60$ & 50.0 \\
Educational level & Single & 0.0 \\
& Married & 100.0 \\
Household size & Primary & 25.0 \\
& Secondary & 50.0 \\
Status & Tertiary & 12.5 \\
& $1-5$ & 50.0 \\
Major source of income & $6-10$ & 50.0 \\
& Full time & 87.5 \\
Other sources of income & Part-time & 12.5 \\
& Horse mussel processing & 87.5 \\
Years of experience & Fishing & 12.5 \\
& Horse mussel collecting & 12.5 \\
& None & 87.5 \\
\hline
\end{tabular}




\begin{tabular}{|c|c|c|c|c|c|}
\hline PROCESS & INPUTS & PRODUCTION & PROCESSING & TRADING & CONSUMPTION \\
\hline INPUT FORM & & Fishing implements & Fresh horse mussels & $\begin{array}{l}\text { Shucked and bottled } \\
\text { horse mussels }\end{array}$ & $\begin{array}{l}\text { Shucked and bottled } \\
\text { horse mussels }\end{array}$ \\
\hline OUTPUT FORM & Fishing implements & Fresh horse mussels & $\begin{array}{l}\text { Shucked and bottled } \\
\text { horse mussels }\end{array}$ & & \\
\hline
\end{tabular}

Fig. 5. Product flow of the horse mussels Modiolus metcalfei in the value chain in Dumangas, lloilo.

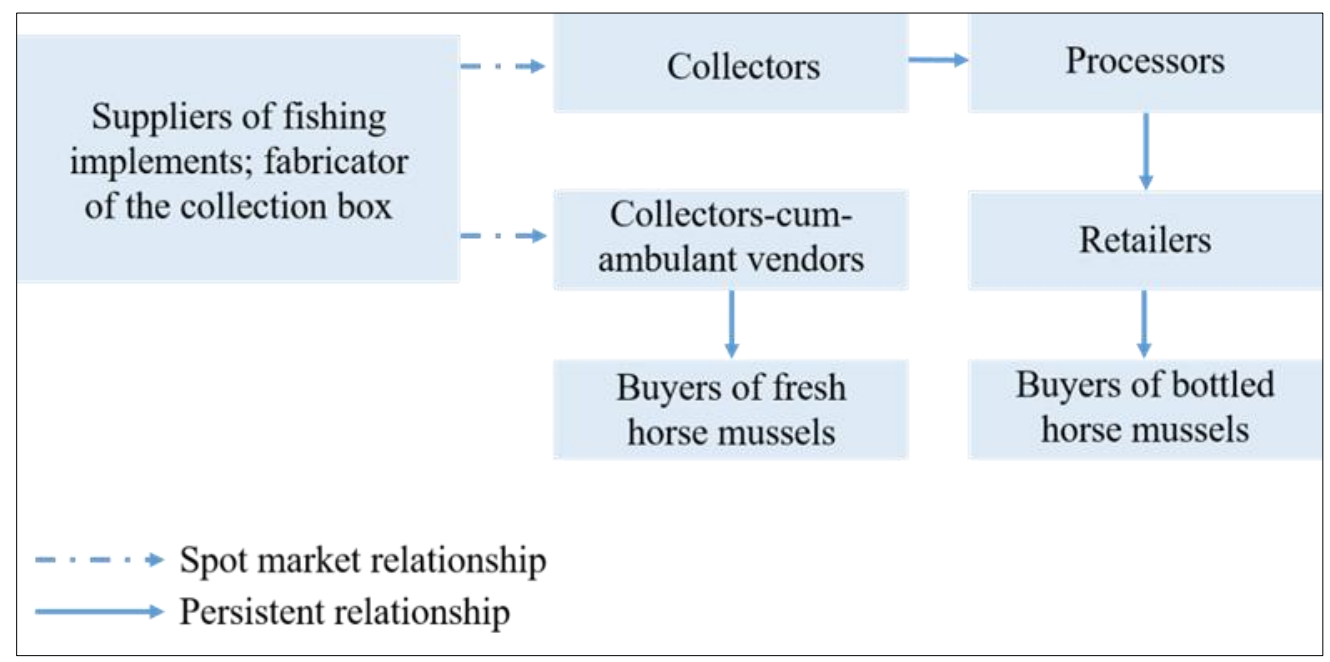

Fig. 6. The relationships and linkages among value chain actors in the horse mussel Modiolus metcalfei fishery in Dumangas, Iloilo.

The horse mussel trade was found to be primarily informal, with no written contracts between actors. The agreements were based on trust, reliability, and long term relationships. Suppliers of fishing implements and fabricators of the collection box maintained a spot market relationship wherein transactions, including negotiations on price and other requirements, with the duration and scope of the transaction, were created "on the spot" (M4P, 2008). On the other hand, the processors to retailers and the collector-cum-ambulant vendors and the retailers to their buyers maintained a persistent relationship. These actors had a preference for transacting with each other over time (M4P, 2008).

Moreover, the suppliers of fishing implements and fabricators of the collection box were closely related to collectors. Furthermore, the collectors and the processors belonged to the same household, thus, there was a continuous flow of information between these players. The processors maintained a close relationship with the suppliers of materials necessary for the processing of horse mussels (coconut vinegar and bottles) and also with the retailers who bought the products by bulk. Some collectors targeted the market for fresh horse mussels while the retailers targeted the market for processed horse mussel products. In general, the actors were bound by suki relationship, that is, a credit/marketing linkage common in the Philippines (Rosales et al., 2017).

\section{Support industries}

Various industries support the horse mussel value chain. The raw materials needed in the processing of horse mussels such as salt, vinegar, and bottles were sourced locally. Salt and vinegar were bought at retail stores within the community. Some processors make their coconut vinegar sourced from coconut trees that they own. Salt and coconut vinegar were purchased at PHP20.00 kg-1 (USD0.4) and PHP25.00 $\mathrm{L}^{-1}$ (USD0.5), respectively. The bottles used as a container of the processed mussel were bought from local recycling shops within Dumangas at PHP2.00 (USD0.04) each.

\section{Policies and legal framework}

In a value chain, governance pertains to rules operating within the chain, including the formal and informal arrangements between actors. The analysis of governance has the objective of examining the rules, both formal and informal, operating in the value chain and the system of coordination, regulation, and control in which value is generated along a chain (M4P, 2008). 
Governance in the horse mussel value chain in Dumangas, lloilo was found to be regulated by the local government. The provincial government formulated policies for the management of horse mussel resources in the area, issued permits for collection, and collected taxes for every sack of horse mussel harvested. Information on the laws and regulations came from the local government and relayed to the horse mussel fisherfolk through their respective barangay officials.

In the horse mussel value chain, a local law was passed to regulate collection. Since 2006, Barangay Bacay, which was the largest horse mussel collection site, had been implementing a regulation to manage horse mussel resources and address issues associated with the extensive collection and increasing volume of harvest. Barangay Ordinance No. 02-2006 imposed a collectable tax and required all horse mussel gatherers and traders/buyers operating in the coastal vicinity of the barangay to secure a barangay clearance and Mayor's permit. A PHP5.00 (USD0.1) tax for every sack was imposed and a maximum of two sacks per collector was allowed per collection day. The minimum size of horse mussel allowed for harvest was $5 \mathrm{~cm}$ and harvest inspection was mandated. This was in response to the unregulated and indiscriminate harvesting of horse mussels in the area. Before the law was crafted and implemented, truckloads of mussels were bought by crab and shrimp growers from Roxas City, Capiz, to be used as feeds. The bulk demand created by this market resulted in a high volume of harvesting, which eventually led to the depletion of the resource. This Barangay Ordinance was put to test in 2007 when an apprehension resulted in confiscation of a truckload of mussels in Barangay Bacay. The depletion of the resource brought about by the overexploitation was exacerbated by the onslaught of Typhoon Haiyan, one of the most powerful tropical cyclones recorded in Panay Island last November 2013. The strong waves brought about by strong winds had scoured the softbottom habitat where the mussels were growing, which resulted in the dislodging of mussels. In 2016, the horse mussel population started to recover and harvesting resumed but harvests were within limits set by the law to make the exploitation of the resource sustainable.

Based on interviews, all gatherers had expressed their agreement to the implementation of harvest limits and access restrictions through securing of permits to gather mussels. Since most of them were dependent on this resource for their daily income, they understood that these policies were aimed at ensuring the sustainability of the resource. However, the weak and inadequate law enforcement caused some gatherers to collect more than what was allowed by law, and disregard the minimum mussel size allowed for harvest. Some even collected without securing a permit before harvesting as there was no certainty of being caught and punished. The barangay ordinance mandated harvest inspection, yet no group was organised to implement the regulation. The councillor for fisheries and aquaculture was the sole barangay official tasked to implement the said regulation and lacked enforcers under his management to implement the ordinance fully.

\section{Value additions along the chain}

The value added at every node of the horse mussel value chain is shown in Figure 7. To standardise the value added at each node in the chain, the monthly income of each actor from collecting, processing, and selling of horse mussels was computed, respectively.

The collector gathered an average of two sacks daily (approximately $50 \mathrm{~kg}$ per sack) and sold it at PHP200.00 (USD4.00) per sack. The collector had a monthly net income of PHP9,597.46 (USD191.95). The collector-cum-ambulant vendor collected one sack daily. Half of the sack was repacked and sold with shell (1/2 sack = 30 packs) at PHP10.00 (USD0.2) per pack while the other half is shucked and the mussel meat was sold at PHP10.00 (USD0.2) per glass (1/2 sack $=30$ glasses of mussel meat).

The collector-cum-ambulant vendor had a monthly net income of PHP10,892.78 (USD217.86). On the other hand, the processor can produce 30 bottled mussels in four days from two sacks of fresh mussels and sold it at PHP35.00 per bottle. Thus, the processor earned only PHP4,185.10 (USD83.70) monthly. Since the processor was often the wife of the collector, it was understood that a family engaged in the horse mussel fishery had a monthly income of PHP13,782.56 (USD275.65). The retailer, who bought the processed mussel in bulk (100 bottles) once a week and sold them at PHP50.00 (USD1.00) per bottle to local markets, had a monthly net income of PHP5,000.00 (USD100.00). The highest value added was at PHP8.30 (USD0.17) $\mathrm{kg}^{-1}$ by the collector-cum-ambulant vendor who earned the most in this value chain while the lowest value addition was at PHP2.30 (USD0.05) $\mathrm{kg}^{-1}$ by the processor who earned the least in this value chain.

The cost at the collector node was limited to fishing implements, taxes and permits for collection, resulting in a higher income. In the collector-cumambulant vendor, the depreciation cost of his motorcycle and the cost of fuel were additional cost incurred. The processor incurred cost in the necessary materials for processing horse mussels into bottled products while the retailer incurred capital costs (for buying the bottled product from the processor) and fare.

\section{SWOT analysis}

Figure 8 shows the strengths, weaknesses, opportunities, and threats of the horse mussel fishery in Dumangas, Iloilo. The opportunities for the 


\begin{tabular}{|c|c|c|c|c|}
\hline & \multicolumn{2}{|c|}{ PRODUCTION } & \multirow{2}{*}{$\begin{array}{l}\text { PROCESSING } \\
\text { PROCESSOR }\end{array}$} & \multirow{2}{*}{$\begin{array}{l}\text { TRADING } \\
\text { RETAILER }\end{array}$} \\
\hline & COLLECTOR & $\begin{array}{l}\text { COLLECTOR-CUM- } \\
\text { AMBULANT VENDOR }\end{array}$ & & \\
\hline EXPENSES $^{1}$ & $\begin{array}{l}\text { PHP 802.54 } \\
\text { (USD 16.05) }\end{array}$ & $\begin{array}{c}\text { PHP 4,707.22 } \\
\text { (USD 94.14) }\end{array}$ & $\begin{array}{l}\text { PHP 6,314.90 } \\
\text { (USD 126.30) }\end{array}$ & $\begin{array}{l}\text { PHP } 15,000.00 \\
\text { (USD 300.00) }\end{array}$ \\
\hline REVENUES & $\begin{array}{l}\text { PHP 10,400.00 } \\
(\text { USD 208.00) }\end{array}$ & $\begin{array}{l}\text { PHP } 15,600.00 \\
{\text { (USD } 312.00)^{3}}\end{array}$ & $\begin{array}{l}\text { PHP } 10,500.00 \\
\text { (USD 210.00) }^{4}\end{array}$ & $\begin{array}{l}\text { PHP 20,000.00 } \\
\text { (USD 400.00) }^{5}\end{array}$ \\
\hline INCOME & $\begin{array}{l}\text { PHP 9,597.46 } \\
\text { (USD 191.95) }\end{array}$ & $\begin{array}{c}\text { PHP 10,892.78 } \\
\text { (USD 217.86) }\end{array}$ & $\begin{array}{c}\text { PHP 4,185.10 } \\
\text { (USD 83.70) }\end{array}$ & $\begin{array}{l}\text { PHP 5,000.00 } \\
\text { (USD 100.00) }\end{array}$ \\
\hline SELLING PRICE & $\begin{array}{l}\text { PHP } 4.00 \mathrm{~kg}^{-1} \\
(\mathrm{USD} 0.08)^{6}\end{array}$ & $\begin{array}{c}\text { PHP } 8.30 \mathrm{~kg}^{-1} \\
\text { (USD 0.17) }^{7}\end{array}$ & $\begin{array}{l}\text { PHP } 10.60 \mathrm{~kg}^{-1} \\
\left(^{-1} \text { USD } 0.21\right)^{8}\end{array}$ & $\begin{array}{l}\text { PHP } 15.15 \mathrm{~kg}^{-1} \\
\text { (USD0.30) }^{9}\end{array}$ \\
\hline VALUE-ADDED & $\begin{array}{l}\text { PHP } 4.00 \mathrm{~kg}^{-1} \\
\text { (USD 0.08) }\end{array}$ & $\begin{array}{c}\text { PHP } 8.30 \mathrm{~kg}^{-1} \\
\text { (USD 0.17) }\end{array}$ & $\begin{array}{l}\text { PHP } 2.30 \mathrm{~kg}^{-1} \\
\text { (USD 0.05) }\end{array}$ & $\begin{array}{l}\text { PHP } 4.55 \mathrm{~kg}^{-1} \\
\text { (USD 0.09) }\end{array}$ \\
\hline $\begin{array}{l}{ }^{1} \text { Includes all cost o } \\
{ }^{2} \text { Estimate for } 2 \mathrm{sac} \\
{ }^{3} \text { Estimate for } 1 \mathrm{sac} \\
\text { glasses) at PHP 10 } \\
{ }^{4} \text { Estimate for a pro } \\
\text { bottles. } \\
{ }^{5} \text { A retailer buys } 10 \\
{ }^{6} \text { One sack of muss } \\
{ }^{7} \text { One sack of fresh } \\
\text { each kilogram cos } \\
{ }^{8} \text { One sack of horse } \\
\text { PHP 35.00. Thus, } \\
{ }^{9} \text { One sack of horse } \\
\text { PHP 50.00. Thus, } \\
{ }^{*} \text { US Dollar to Phil }\end{array}$ & $\begin{array}{l}\text { depreciation co } \\
\text { larvest sold at } P \\
\text { arvest. Half of } \mathrm{t} \\
00 \text { bottles per } \mathrm{n} \\
\text { week and sells } \\
\text { imately } 50 \mathrm{~kg} \text { ar } \\
\text { els can be repac } \\
\mathrm{kg} \text { ) can be ma } \\
\mathrm{r} \text { kilogram is at } \\
\mathrm{kg} \text { ) can be ma } \\
\mathrm{r} \text { kilogram is at } \\
\text { exchange rate i }\end{array}$ & $\begin{array}{l}.00 / \text { sack. One sack is ap } \\
\text { is sold shell-on per pack } \\
\text { old at PHP } 35.00 \text { /bottle. } \\
\text { IP } 50.00 / \text { bottle in key to } \\
\text { at PHP } 200.00 \text {. Thus, ea } \\
60 \text { packs (with shell). } \\
15 \text { bottles of processed n } \\
.60 \text {. } \\
15 \text { bottles of processed n } \\
.15 \text {. } \\
\text { ed at PHP } 50.00 \text { : USD } 1\end{array}$ & $\begin{array}{l}50 \mathrm{~kg} . \\
\text { at PHP } 10.00 / \text { pack an } \\
\text { processes } 2 \text { sacks eve } \\
\text { costs Php } 4.00 \text {. } \\
\text { estimated to be } 0.83 \\
\text { Is, each bottle require } \\
\text { Is, each bottle require }\end{array}$ & $\begin{array}{l}\text { ck is sold shucked }(30 \\
\text { PHP } 10.00 / \text { pack. Thus, } \\
\text { ke. A bottle is sold at } \\
\text { ke. A bottle is sold at }\end{array}$ \\
\hline
\end{tabular}

Fig. 7. Monthly expenses, revenues, and income of each actor in the horse mussel Modiolus metcalfei value chain in Dumangas, Iloilo. The value and value-added in each actor are also reflected.

\begin{tabular}{|c|c|c|c|c|}
\hline Strengths & Weaknesses & & Opportunities & Threats \\
\hline - Locally available materials & - A disorganised fisherfolk & $\begin{array}{l}\text { Z } \\
\text { ড̆ }\end{array}$ & - Organise fisherfolk & \\
\hline - Rich brown mussel resources & - Rich brown mussel resources & & - Potential for poverty reduction & - Overexploitation \\
\hline - Regulated harvesting & - Regulated harvesting & 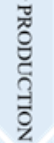 & - Source of employment & $\begin{array}{l}\text { - Typhoons } \\
\text { - Pollution }\end{array}$ \\
\hline $\begin{array}{l}\text { - Longer shelf-life } \\
\text { - Potential for business }\end{array}$ & $\begin{array}{l}\text { - Poor sanitation, packaging, } \\
\text { and labelling } \\
\text { - Lack of post-harvest } \\
\text { infrastructure }\end{array}$ & 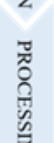 & $\begin{array}{l}\text { - Many products can be } \\
\text { developed from mussels }\end{array}$ & \\
\hline $\begin{array}{l}\text { - Potential high profits and rates } \\
\text { of returns } \\
\text { - Employs women }\end{array}$ & - Prices are not standardised & 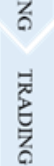 & - Standardise prices & - Monopoly of production \\
\hline $\begin{array}{l}\text { - Healthy food option } \\
\text { - Flavors can be enhanced }\end{array}$ & - Small local market & $\begin{array}{l} \\
\delta \\
0 \\
0 \\
\vdots \\
5 \\
3 \\
0 \\
Z \\
Z\end{array}$ & $\begin{array}{l}\text { - Higher demand for mussel } \\
\text { products }\end{array}$ & $\begin{array}{l}\text { - Harmful algal blooms } \\
\text { - Food poisoning }\end{array}$ \\
\hline
\end{tabular}

Fig. 8. Strengths, weaknesses, opportunities, and threats of the horse mussel Modiolus metcalfei fishery in each node in the value chain in Dumangas, lloilo.

improvement of the horse mussel fishery aroused from the support of the local government as the main enabler and the academe as the research arm. The area had a rich horse mussel resource with a high potential for profits. Also, it was advantageous that the policies regulating the exploitation of the resource were already in place. 
On the other hand, the constraints to this fishery included the lack of adequate law enforcement, lack of support from the enablers, lack of post-harvest infrastructure, and disorganised fisherfolk. The threats to this fishery can be anthropogenic and natural. Anthropogenic threats included pollution, overexploitation, and food safety concerns which can be avoided if adequate measures were taken while natural threats included the occurrence of harmful algal blooms and prevalence of bad weather conditions, mainly typhoons.

\section{Upgrading and enabling strategies in the horse mussel value chain}

In every node in the horse mussel value chain, suggestions for upgrading were proposed along with its enabling strategies (Fig. 9). In the production node, the organisation of the horse mussel fisherfolk and the creation of a local fishery cooperative can maximise long-term community benefits to deal with the threats of fisheries mismanagement, livelihood insecurity, and poverty. In the processing node, the diversification of horse mussel products, improvement of packaging and labelling, adherence to good manufacturing practices, and integration of processing and trading are proposed. Also, integration of trading and wholesaling, expansion of product distribution in ports and terminals, gift/souvenir centres, and eateries are proposed. These upgrading strategies can be successful through the establishment of business linkages, strict enforcement of existing policies, and capacity building.

\section{Discussion}

A value chain analysis provides a different perspective on small-scale fishery compared to a traditional socioeconomic or resource and ecological assessment. It involves an examination of how the individual actors operate, what is going on between the actors in the chain, what keeps the actors together, what information is shared, what power relationships exist, and how the relationships evolve (Kaplinsky and Morris, 2001; Jacinto and Pomeroy, 2011). Moreover, due to the high incidence of poverty in the small-scale fisheries sector, the value chain framework can also be used to conclude the participation of the poor and the potential impact of value chain development on poverty reduction (Rosales et al., 2017; Roxas et al., 2017).

The horse mussel fishery in the study area is smallscale, involving only about a hundred people. The value chain is non-complex and straightforward. A whole household is involved in this trade. Men collect mussels while women and children transform the product. Both men and women may do marketing. This is consistent with the observations of other studies where men are typically engaged in strenuous activities while women are in activities needing patience and meticulous attention (Ferrer et al., 2014; Sumagaysay, 2014). The utilisation of members of the household as unpaid workers is a strategy adopted in the horse mussel trade. This is to cope with poverty, as this results to lower operational expenses and additional family income (Silvander, 2013; Roxas et al., 2017). Moreover, it was evident that the livelihood

\begin{tabular}{|c|c|c|c|}
\hline & PRODUCTION & PROCESSING & TRADING \\
\hline 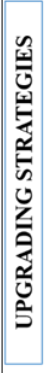 & $\begin{array}{l}\text { - Organise horse mussel } \\
\text { fisherfolk to create a local } \\
\text { cooperative }\end{array}$ & $\begin{array}{l}\text { - Diversify horse mussel } \\
\text { products: } \\
\text { - Mussel crackers } \\
\text { - Mussel sauce } \\
\text { - Mussel paste } \\
\text { - Shell craft making } \\
\text { - Improve packaging and } \\
\text { labelling to become more } \\
\text { acceptable to both domestic and } \\
\text { international markets } \\
\text { - Adherence to good } \\
\text { manufacturing practices } \\
\text { - Integrate processing and trading }\end{array}$ & $\begin{array}{l}\text { - Integrate trading and } \\
\text { wholesaling } \\
\text { - Expand product distribution } \\
\text { throughout the country } \\
\text { - Stalls in ports or public } \\
\text { utility vehicles terminals } \\
\text { - Gift/souvenir centres } \\
\text { - Eateries }\end{array}$ \\
\hline 愛 & - Horse mussel seed production & $\begin{array}{l}\text { - Post-harvest facilities } \\
\text { products } \\
\text { - Shared service facilities }\end{array}$ & $\begin{array}{l}\text { - Standardisation of prices } \\
\text { - Market research } \\
\text { saturation }\end{array}$ \\
\hline 竞 & \multicolumn{3}{|c|}{$\begin{array}{l}\text { Establish linkages with businesses: organisation of horse mussel fisherfolk; cooperatives; vertical and horizontal } \\
\text { linkages }\end{array}$} \\
\hline 岁 & \multicolumn{3}{|c|}{$\begin{array}{l}\text { Strict enforcement of existing policies: local ordinances (harvest regulations); product standards; environment } \\
\text { standards }\end{array}$} \\
\hline Z & \multicolumn{3}{|c|}{$\begin{array}{l}\text { Capacity building: Training on food safety; skills training; entrepreneurial skills training; basic accounting and } \\
\text { bookkeeping training }\end{array}$} \\
\hline 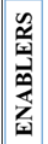 & \multicolumn{3}{|c|}{$\begin{array}{l}\text { Local Government of Dumangas; Bureau of Fisheries and Aquatic Resources; Department of Agriculture; } \\
\text { Academe; Bureau of Food and Drugs; Department of Trade and Industry; micro-finance and lending institutions; } \\
\text { non-government organisations }\end{array}$} \\
\hline
\end{tabular}

Fig. 9. Upgrading and enabling strategies for the horse mussel Modiolus metcalfei value chain in Dumangas, Iloilo. 
options of these communities were diversified. Livelihood diversification in coastal communities where households engage in multiple incomegenerating activities is a strategy for spreading risk and reducing vulnerability (Allison and Ellis, 2001; Brugere et al., 2008; Gordon and Pulis, 2010). When compared to the monthly income of agricultural workers in the same region, the collectors and collector-cum-ambulant vendors have higher income while the processors and retailers have lower income (Wage Order No. RBVI-25, 2019). Thus, livelihood diversification, as a strategy against poverty, may help augment income among the actors.

Gatherers claimed that the horse mussel beds had become sparse through time, indicating an overexploited condition. Moreover, indications of a deteriorating habitat condition were reported by Uba et al. (2019). Thus, management measures have been adapted in the area. Harvest control regulations such as size limit, maximum volume of harvest, and frequency of harvesting are implemented through an ordinance. Moreover, given the small-scale nature of this fishery, there were no proper records of its volume of production (Decastillo Jr., pers. comm.). The lack of adequate enforcement of the laws, minor support from the enablers, and lack of infrastructure on post-harvest hindered the full potential of this fishery. The same problems were reported by Brown et al. (2010), Roxas et al. (2017), Rosales et al. (2017), and Jontila et al. (2018) on their study of the value chains of small-scale fisheries in the country.

Sea ranching of horse mussels can be explored as a viable option to increase the volume of horse mussel production in the area when a developed aquaculture technology for the species becomes available. Sea ranching may, however, be disadvantageous, in the long term, towards local horse mussel collectors and processors if such efforts are left in the hands of investors who would get huge profits from such investments. Given equitable income distribution and resource sustainability, future sea ranching efforts may be made only by the local government for seed stock enhancement as a part of a sound management approach.

The evaluation of the horse mussel value chain revealed the need for improvement in the current setup. Support measures should be enhanced. The local government's role as the regulatory agency is important in this fishery. However, it was evident that mandatory inspection of harvest, if within limits set by the law, were not implemented. Thus, several gatherers harvested beyond what the law allowed (some harvesting four sacks per collection). If left unchecked, this might result in resource depletion. While gatherers acknowledged the importance of adhering to the law, meeting the basic needs of the household were their top priority. Moreover, scientific data, to create a sound fisheries management framework for the sustainable exploitation of this resource, was limited. Also, the disorganised horse mussel fisherfolk is a hindrance in effectively managing this resource. An organisation should be created to have an integrated approach in management where the crafting of policies involves fisherfolk consultations and programs for the improvement of this fishery from the government can be easily implemented. Without an existing organisational structure, the improvement of this fishery is hindered. Furthermore, there should be compliance among processors on the food safety standards in the country. It was observed that processors did not obtain sanitary permits before processing.

Furthermore, diversification of horse mussel products is seen as an upgrading strategy to increase the income of the processor. Given that this is a household activity, the increase in revenue at the processor node may ease pressures on the horse mussel resource as collectors may opt to follow the harvest limits set by law. The income of the retailer increased with the expansion of the distribution of horse mussel products in local ports and terminals. Also, selling of horse mussel products in local and regional gift/souvenir centres may introduce the product to consumers, thereby enabling market expansion and penetration. At present, capacity building efforts for horse mussel fisherfolk are lacking. Training and workshops on basic food safety practices should be conducted to capacitate the processors.

Moreover, there is a need to assist processors in improving products in terms of packaging, labelling, and marketing. However, a progressive approach is first to solve labour and time constraints to horse mussel processing through the mechanisation of some, if not all, processes. Mechanisation is seen as a prerequisite to product diversification and market expansion because it would require a bigger volume of horse mussels to be processed.

Although the horse mussel industry is small-scale, the present value chain analysis shows that it provides a relatively equitable income source to many poor income households. The absence of great inequities in the income among actors in the chain may be attributed to 1) simple and direct marketing pathway between collectors and consumers and 2) maintenance of transparency among value chain actors. The existence of a simple and direct marketing pathway in this value chain is owed to the absence of middlemen who disproportionately capture wealth among value chain actors (Purcell et al., 2017). Furthermore, the structure of the horse mussel value chain maintains transparency among all value chain actors. This prevents exploitative social relations among actors in the chain (Jacinto and Pomeroy, 2011; Purcell et al., 2017). 
Maintaining equitable income distribution among value chain actors while improving the income in each actor is challenging. Often, down-stream value chain actors received less revenue due to poor knowledge of the market value of the products (Ram et al., 2014; Purcell et al., 2016), and therefore cannot bargain for higher prices from succeeding actors. Thus, increasing information on transparency in the value chain is imperative. However, better prices will only come when fishers are able to organise themselves to gain greater market power as a collective. Thus, organising a horse mussel cooperative may be necessary to maintain equitable income distribution among actors in the value chain. Also, the standardisation of prices by the local government may empower fishers and help safeguard them from unscrupulous practices of certain traders.

The horse mussel value chain is unique such that there are no wholesalers involved. However, in the past, wholesalers from the province of Capiz purchased truckload of horse mussels used as feed for farmed shrimps and crabs. The fear that this practice would result in the collapse of the resource urged the local government to ban the practice through an ordinance. The horse mussel fishery is not only beneficial to small scale fishers but also has potential in addressing sustainable development goals (UN-SDGs, 2019). The horse mussel fishery may help alleviate poverty and end hunger by ensuring food security and improved nutrition. Also, it supports gender equality as women play a crucial role in this fishery. Although imperfect, the management practices being implemented in the area are also aligned towards the conservation and sustainable use of the horse mussel resources. Thus, there is a need to recognise the huge potentials of such fisheries and ensure its sustainable management.

\section{Conclusion}

The horse mussel fishery in Dumangas, lloilo supported households that were engaged in the collection, processing, and trading of this resource. Although small-scale, it required small investments and allowed the participation of women not just in the collection and trading processes but primarily in postharvest. However, the industry lacked adequate policies to ensure resource sustainability and adherence to product standards. Also, enforcement of fishery laws, support from the enablers, and infrastructure for post-harvest processing seemed to be wanting. Furthermore, disorganised fisherfolk hindered effective collaboration between resource users and the local government. Although product diversification is seen as an important means to expand the current local market, improvement of post-harvest infrastructure through the mechanisation of some, if not all, processes may address time and labour constraints to horse mussel processing. Product diversification and entry to new markets, in the future, will require a bigger volume of processed horse mussels. As the resource exhibited signs of overexploitation, sea ranching should be considered as a viable option in consideration of equitable income distribution and resource sustainability, although technologies for such need to be developed. These areas of improvement, if addressed, will maximise the full economic potential that can be generated from this fishery.

\section{Acknowledgements}

The authors are thankful to the Commission on Higher Education - K to 12 Transition Program Scholarship for Graduate Studies and the University of the Philippines Visayas- Office of the Vice-Chancellor for Research and Extension for the funding support. The support of the DOST-UPV Invasive Mussel Project and the local government of Dumangas are greatly appreciated.

\section{References}

Allison, E.H., Ellis, F. 2001. The livelihoods approach and management of small-scale fisheries. Marine Policy 25:377-388. https://doi.org /10.1016/S0308-597X(01)00023-9

Brown, E.O., Perez, M.L., Garces, L.R., Ragaza, R.J., Bassig, R.A., Zaragoza, E.C. 2010. Value chain analysis for sea cucumber in the Philippines. Studies and Reviews 2120. The WorldFish Center, Penang, Malaysia. $44 \mathrm{pp}$.

Brugere, C., Holvoet, K., Allison, E.H. 2008. Livelihood diversification in coastal and inland fishing communities: misconceptions, evidence and implications for fisheries management. Working paper, Sustainable Fisheries Livelihoods Programme (SFLP). FAO/DFID, Rome. 39 pp.

Ferrer, A.J.G., Perez, M.L., Roxas, A.T., Avila, E.M. 2014. Expanding roles of men and women in aquatic agricultural systems in the Philippines. Asian Fisheries Science 27(S):185-194.

Gordon, A., Pulis, A. 2010. Livelihood diversification and fishing communities in Ghana's western region. WorldFish Center, USAID Integrated Coastal and Fisheries Governance Initiative for the Western Region, Ghana. 69 pp.

Jacinto, E.R., Pomeroy, E.M. 2011. Developing markets for small-scale fisheries: utilizing the value chain approach. In: Small-scale fisheries management: frameworks and approaches for the developing world Pomeroy, R.S., Andrew, N. (Eds), pp. 160-177. CABI Publishing, Cambridge, MA, USA.

Jontila, J.B.S., Monteclaro, H.M., Quinitio, G.F., Santander-de Leon, S.M., Altamirano, J.P. 2018. Status of sea cucumber fishery and populations across sites with different levels of management in Palawan, Philippines. Ocean and Coastal Management 165:225-234. https://doi.org/10.1016/j.ocecoaman.2018.08.025

Kaplinsky, R., Morris, M. 2001. A handbook for value chain research. International Development Research Center, Ottawa, Canada. 109 pp.

Monteclaro, H.M., Anraku, K., Uno, S., Koyama, J., Masuoka, T., Quinitio, G.F. 2010. Water quality degradation and its effect on fishing activities. Memoirs of Faculty of Fisheries Kagoshima University Special Issue:47-51.

M4P. 2008. Making value chains work better for the poor: a toolbook for practitioners of value chain analysis, version 3. Making markets work better for the poor (M4P) Project, UK Department for International Development. Agricultural Development International, Phnom Penh, Cambodia.145 pp. 
Napata, R.P., Andalecio, M.N. 2011. Exploitation and management of brown mussel (Modiolus philippinarum) resources in lloilo, Philippines. Philippine Journal of Social Science and Humanities 16:22-34.

National Statistics Office. 2010. Census on population and housing. Report no. 1-I Region VI-Western Visayas, Population by Province, City/Municipality, and Barangay. National Statistics Office. 139 pp.

Porter, M. 1985. Competitive advantage: Creating and sustaining superior performance. Free Press, New York, USA. 557 pp.

PSA. 2018. Fisheries statistics of the Philippines, 2014-2016, Volume 25. Philippine Statistics Authority, Quezon City, Philippines. 299 pp.

Purcell, S.W., Crona, B.I., Lalavanua, W., Eriksson, H. 2017. Distribution of economic returns in small-scale fisheries for international markets: a value chain analysis. Marine Policy 86: 9-16. https://doi.org/10.1016/j.marpol.2017.09.001

Purcell, S.W., Ngaluafe, P., Aram, K.T., Lalavanua, W. 2016. Variation in post-harvest processing of sea cucumbers by fishers and commercial processors among three Pacific Island countries. SPC Beche-De-Mer Information Bulletin 36:58-66.

Ram, R., Chand, R.V., Southgate, P.C. 2014. Effects of processing methods on the value of bêche-de-mer from the Fiji Islands. Journal of Marine Science: Research and Development 4:1-7. https://doi.org/10.4172/2155-9910.1000152

Rochanaburanon, T. 1980. A comparison of macronutrient levels in Green mussel (Perna viridis) and Brown mussel (Modiolus metcalfei Hanley). Journal of the Science Society of Thailand 6:191-197.

Rosales, R.M., Pomeroy, R., Calabio, I.J., Batong, M., Cedo, K., Escara, N., Facunla, V., Gulayan, A., Narvadez, M., Sarahadil, M., Sobrevega, M.A. 2017. Value chain analysis and small-scale fisheries management. Marine Policy 83:11-21. https://doi.org/10.1016 /j.marpol.2017.05.023

Roxas, A.T., Guliman, S.D., Perez, M.L., Ramirez, P.J. 2017. Gender and poverty dimensions in a value chain analysis of Milkfish mariculture in Misamis Oriental, Philippines. Asian Fisheries Science 30(S):343353.

Silvander, J.K. 2013. Gender equality in value chains and the role of aid for trade in promoting gender equality and women's employment in developing countries. Ministry for Foreign Affairs, Finland. 60 pp.

Sinh, L.X., Navy, H., Pomeroy, R.S. 2014. Value chain of snakehead fish in the lower Mekong Basin of Cambodia and Vietnam. Aquaculture Economics and Management 18: 76-96. https://doi.org/10.1080 /13657305.2014.855956

Sumagaysay, M.B. 2014. Workspaces for women in the mussel industry value chain of Jiabong, Samar in the Philippines: promoting smallscale entrepreneurship. Asian Fisheries Science 27(S):175-184.

Uba, K.I.N., Monteclaro, H.M., Noblezada-Payne, M.M.P., Quinitio, G.F. 2019. Sexual dimorphism, asymmetry, and allometry in the shell shape of Modiolus metcalfei (Hanley, 1843) collected from Dumangas, Iloilo, Philippines: A geometric morphometric approach. Computational Ecology and Software 9:107-120.

UN-SDGs. 2019. United Nations Sustainable Development Goals Platform. https://sustainabledevelopment.un.org/sdgs (Accessed 28 April 2020).

Wage Order No. RBVI-25. 2019. Providing for the new minimum wage rates in Western Visayas. Department of Labor and Employment, National Wages and Productivity Commission, Regional Tripartite Wages and Productivity Board, Jaro, lloilo City. 6 pp.

Yap, W.G. 1978. Settlement preference of the brown mussel, Modiolus metcalfei, Hanley and its implication on the aquaculture potential of the species. Fisheries Research Journal of the Philippines 3:65-70. 